\title{
THE USE OF THE PENICILLINASE-RESISTANT PENICILLIN IN THE PNEUMONIAS OF CHILDREN
}

\author{
Martha D. Yow, Mary A. South and Charles G. Hess \\ From the Department of Pediatrics, Baylor University College of Medicine, \\ Houston, Texas.
}

WE have had the impression that during the past six years (1958-1964), the morbidity and mortality rates of bacterial pneumonias in pediatric patients at Ben Taub General Hospital in Houston have been less than those of the previous four years (1954-1957). Since pneumonia are the most common types of pneumonia in children admitted to the hospital, a survey of the experiences with these two types of pneumonia was carried out. There was little change in either the morbidity or mortality rates in pneumococcal pneumonia. Analysis of 54 cases of proven primary staphylococcal pneumonia revealed a mortality rate of $11 \%$ from 1954 through $1957,6.3 \%$ from 1957 through 1960, and there were no deaths from 1961 through May 1964. (Table I).

This decrease in mortality figures led to the consideration of the factors which may have been operative in producing the changes. The medical personnel responsible for patient care has been constant throughout the ten year period, symptomatic measures have remained the same, techniques of surgical drainage of empyema have remained fairly constant, but the etiologic strains of staphylococci have varied considerably. The strains from 1954 through 1956 were of miscellaneous phage types and approximately $50 \%$ were penicillinresistant. An epidemic strain (phage 42B, 81, $44 \mathrm{~A}, 70$ ) which was resistant to penicillin, tetracycline, streptomycin, and erythromycin pneumococcal pneumonia and staphylococcal

produced a large proportion of the cases of staphylococcal pneumonia during the latter part of 1957 and 1958. From 1959 through May, 1964 the cases of staphylococcal pneumonia were again due to miscellaneous strains, $66 \%$ of which were penicillin-resistant.

The other major factor which has altered during the last ten years was the selection of antibiotic agents for the management of all serious cases of pneumonia in young children. The selection was particularly altered during the early course of the disease while results of bacteriologic studies were pending. During the years 1954 through 1957, the majority of patients were treated with penicillin alone or penicillin in combination with erythromycin, chloramphenicol, novobiocin. There were so many treatment failures employing thise regime that in 1958 bacitracin and kanamycin were used. Morbidity was decreased using? these drugs. There were two deaths during this period but both of the deaths occurred in children who had failed to respond to penicillin and had advanced pathology when kanamycin was instituted.

Since the advent of the first penicillinaseresistant penicillin, methicillin, either methicillin or one of the other penicillinaseresistant penicillins has been used alone or in combination with penicillin $G$ for the initiation of treatment in the majority of severely ill patients in whom the possibilities of staphylococcal or pneumococcal pneumonia

TABLE I

Antibiotic Management of 54 cases of Primary Staphylococcal Pneumonia 1954-1964

\begin{tabular}{|c|c|c|c|c|c|c|c|}
\hline Years & Antibiatics & $\underset{\text { Patients }}{\text { Number of }}$ & Recoveries & $\begin{array}{l}\text { Treatment } \\
\text { Failures }\end{array}$ & Deaths & $\%$ & Mortality \\
\hline 1954-1957 & $\begin{array}{l}\text { Penicillin, Erythromycin, } \\
\text { Chloramphenicol, Novobiocin } \\
\text { (Alone or in various combinations) }\end{array}$ & 18 & 3 & 15 & 2 & & $11 \%$ \\
\hline $1958-1960$ & Bacitracin or Kanamycin & 26 & 24 & 2 & $* 2$ & & $6.3 \%$ \\
\hline $1961-1964$ & Methicillin or Kanamycin & 10 & 10 & 0 & 0 & & 0 \\
\hline
\end{tabular}

* Treatment with kanamycin was instituted late in the course of both of these patients' illness after empyema had developed while being treated with other antibiotics. 
were considered. When the etiologic agent and its antibiotic sensitivity pattern were accurately determined, the appropriate agent was used alone. The penicillinase-resistant penicillins were employed for staphylococcal pneumonia and penicillin $G$ was generally used for pneumococcal pneumonia. However, a small number of patients with disease due to Streptococcus pneumonice have purposely been treated with methicillin, oxacillin or cloxacillin in order to assess the efficacy of these drugs.

Methicillin was effective in the management of staphylococcal pneumonia. It was also found to be effective in pneumococcal disease. All of the patients with uncomplicated pneumococcal pneumonia treated with methicillin alone responded satisfactorily. There was prompt clearing of pneumococcal bacteremia and none of the patients developed empyema or other purulent complications during the course of treatment.

Experience with oxacillin at Ben Taub General Hospital is too limited to permit an evaluation of its efficacy.

The parenteral form of cloxacillin has been used during the past six months. As an illustration of our experiences with the penicillinase-resistant penicillins in the management of pneumonias of infancy and childhood, 25 cases of bacterial pneumonia treated with cloxacillin are presented in this paper.

\section{Cloxacillin Study}

Description of Patients: The age range of the children enrolled in the study was two months to seven years. Fifteen were under one year of age, six were from 1-2 years of age, and four were between the ages of two and seven years. All of the children were seriously ill. There were 11 patients who had bronchopneumonia, seven with lobar pneumonia, and seven who had bronchopneumonia or lobar pneumonia complicated by empyema.

Etiologic Agents: It was the aim of this study to include cases of pneumonia due to Staphylococcus aureus, Streptococcus pneumonio, and the group A hemolytic streptococci. Rigid criteria were established for the implication of a given organism as the etiologic agent. The causative organism was considered to be definitely established only in those cases in which it was isolated from the blood or pleural exudate. In instances where the pneumococcus, staphylococcus or hemolytic streptococcus was the predominant organism in throat smears and cultures, theses organisms were classified as the "probable" $\stackrel{0}{2}$ causative agents. In a third group of patients with bacterial pneumonia an etiologic agent could not be established. These patients were classified as having disease due to unknown etiology. The number of patients studied in each etiologic category is listed in Table II.

TABLE II

The Etiologic Classification of 25 Cases of Pneumonia Treated with Cloxacillin

Pneumococcal Pneumonia

Staphylococcal Pneumonia

Probable Pneumococcal Pneumonia ...

Probable Staphylococcal Pneumonia ...

Probable Streptococcal Pneumonia

Pneumonia of Unknown Etiology

The antibiotic sensitivity patterns of theo causative bacteria were determined using discand tube dilution techniques. The minimaN inhibitory concentrations of penicillin $G$ and? cloxacillin required for a bactericidal effect are shown in Table III.

TABLE III

Range of M.I.C. Values $(\mu \mathrm{g} . / \mathrm{m} \mathrm{\Phi} .)^{\mathbb{D}}$

Organism Penicillin G Cloxacilîn

Str. pneumoniæ $\quad 0.01-0.10$

(6 strains)

Staph. aureus (3 strains) $>25$

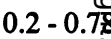

0.78

Cloxacillin Dosage: Twenty patients received cloxacillin by the intramuscular route alone, $\stackrel{\mathbb{Q}}{\varrho}$ four received parenteral cloxacillin early in $\overrightarrow{\vec{B}}$ the course of their disease and oral cloxa-3 cillin later, and one patient was treated with? the oral preparation alone. Cloxacillin was. administered on a per kilogram body weighto basis since the patients varied in size from 3 . 2.7 to 21 kilograms. The dose of intra-o muscular cloxacillin ranged from 35. $\mathrm{mg}$./ kg./day to $200 \mathrm{mg}$./kg./day with the majority of patients receiving $60-100$ $\mathrm{mg} . / \mathrm{kg}$./day. The oral dose ranged from 50 to응 $120 \mathrm{mg} . / \mathrm{kg}$./day. The total daily dose, using $D$ both forms, was divided into six doses. Local instillation of cloxacillin into the pleural space $N$ was utilized in the treatment of three patients with empyema. The dose employed was 10 o mg. (2 mg. $/ \mathrm{ml}$. in $5 \mathrm{ml}$. of normal saline). The average duration of treatment in uns complicated pneumonia was 12 days with ae range of 7-21 days. The average duration of the treatment of pneumonia with empyema? was 21 days with a range of 14-34 days. 
TABLE IV

Mean Serum Concentrations $(\mu \mathrm{g} . / \mathrm{ml}$.) of Cloxacillin after a Single Intramuscular Dose (Three Subjects)

\begin{tabular}{cccccc}
\hline $\begin{array}{c}\text { Hours Following } \\
\text { Injection }\end{array}$ & $6 \mathrm{mg} . / \mathrm{kg}$. & 9 & $\mathrm{mg} . / \mathrm{kg}$. & $12 \mathrm{mg} . / \mathrm{kg}$. & $18 \mathrm{mg} . / \mathrm{kg}$. \\
$1 / 2$ & 5.6 & 9.9 & 13.5 & 15 \\
1 & - & - & - & 12.9 & 11.5 \\
2 & - & - & Trace & -1.5 \\
\hline
\end{tabular}

TABLE V

Analysis of Six Cases of Pneumonia with Empyema

\begin{tabular}{|c|c|c|c|c|c|c|}
\hline Patient & Age & $\begin{array}{c}\text { Etiologic } \\
\text { Agent }\end{array}$ & $\begin{array}{l}\text { Source of } \\
\text { Organism }\end{array}$ & $\begin{array}{l}\text { Duration of } \\
\text { Illness Prior } \\
\text { to Treatment }\end{array}$ & $\begin{array}{l}\text { Cloxacillin Dose } \\
\text { mg./kg./day I.M. }\end{array}$ & Result \\
\hline M. G. & 11 mos. & Pneumococcus & $\begin{array}{l}\text { Throat } \\
\text { Blood } \\
\text { Empyema } \\
\text { Fluid }\end{array}$ & 1-4 days & $\begin{array}{l}100 \times 14 \\
\text { Changed to } \\
\text { Penicillin } G \\
\text { from day } 14 \\
\text { to day } 21\end{array}$ & $\begin{array}{l}\text { Prolonged morbidity probably } \\
\text { due to inadequate drainage. } \\
\text { Culture of empyema fluid was } \\
\text { negative on day } 6 \text {. No interim } \\
\text { cultures. No marked alteration } \\
\text { of course by change to peni- } \\
\text { cillin } G \text {. }\end{array}$ \\
\hline J. M. & 19 mos. & Pneumococcus & $\begin{array}{l}\text { Throat } \\
\text { Blood } \\
\text { Empyema } \\
\text { Fluid }\end{array}$ & 7 days & $\begin{array}{l}35 \times 15 \\
130 \times 4 \\
\text { Intrathoracic } \\
(10 \mathrm{mg} . \times 2) \\
\text { Changed to } \\
\text { Penicillin } \mathrm{G} \\
\text { from day } 19 \text { to } \\
\text { day } 35\end{array}$ & $\begin{array}{l}\text { Prolonged morbidity probably } \\
\text { due to inadequate drainage. } \\
\text { Possibly influenced by low } \\
\text { dose of cloxacillin. Culture of } \\
\text { empyema fluid was negative } \\
\text { on day } 12 \text {. No interim cul- } \\
\text { tures. No significant change } \\
\text { in course after change to } \\
\text { penicillin G. }\end{array}$ \\
\hline V.H. & 4 mos. & Pneumococcus & $\begin{array}{l}\text { Throat } \\
\text { Blood } \\
\text { Empyema } \\
\text { Fluid }\end{array}$ & 7 days & $\begin{array}{l}70 \times 2 \\
\text { Changed to } \\
\text { Penicillin } G \\
\text { day } 3 \text { to day } 26\end{array}$ & $\begin{array}{l}\text { Prolonged morbidity probably } \\
\text { due to inadequate drainage. } \\
\text { Culture of empyema fluid was } \\
\text { negative after } 48 \text { hours of } \\
\text { cloxacillin therapy. Course } \\
\text { similar to those of } M \text {. G. and } \\
\text { J. M. despite early initiation } \\
\text { of pencillin } G \text { therapy. }\end{array}$ \\
\hline R. B. & 18 mos. & Pneumococcus & $\begin{array}{l}\text { Throat } \\
\text { Blood } \\
\text { Empyema } \\
\text { Fluid }\end{array}$ & 1 day & $\begin{array}{l}75 \times 4 \\
150 \times 30 \\
\text { Intrathoracic } \\
(10 \mathrm{mg} . \times 1)\end{array}$ & $\begin{array}{l}\text { Prolonged morbidity. Defin- } \\
\text { itely due to inadequate drain- } \\
\text { age. Culture of empyema } \\
\text { fluid negative on day } 5 \text { of } \\
\text { cloxacillin therapy. Dramatic } \\
\text { response when good drainage } \\
\text { established. }\end{array}$ \\
\hline C. $S$. & 4 mos. & Staphylococcus & $\begin{array}{l}\text { Throat } \\
\text { Empyema } \\
\text { Fluid }\end{array}$ & 3 days & $\begin{aligned} & 85 \times 6 \\
& 170 \times 6 \\
& 50 \times 5 \text { Oral } \\
& 100 \times 5 \\
& \text { Intrathoracic } \\
&(10 \mathrm{mg} . \times 1)\end{aligned}$ & $\begin{array}{l}\text { Prolonged morbidity due } 1.0 \\
\text { inadequate drainage. Organ- } \\
\text { isms still present in empyema } \\
\text { fluid after } 7 \text { days of cloxacil- } \\
\text { lin therapy. No reaccumulation } \\
\text { after adequate drainage. }\end{array}$ \\
\hline W. E. & 15 mos. & Staphylococcus & $\begin{array}{l}\text { Empyema } \\
\text { Fluid }\end{array}$ & 2-3 days & $\begin{array}{r}60 \times 14 \\
120 \times 7 \text { (oral) }\end{array}$ & $\begin{array}{l}\text { Prolonged morbidity due to } \\
\text { inadequate drainage. Organ- } \\
\text { isms still present after } 11 \text { days } \\
\text { of cloxacillin therapy. Drama- } \\
\text { tic improvement after estab- } \\
\text { lishment of adequate drainage. }\end{array}$ \\
\hline
\end{tabular}


Serum Levels: Serum concentrations of cloxacillin were determined following a single intramuscular dose which was approximately one-sixth of the total 24 hour dose. The levels were determined in 3 patients when they were receiving doses of $35 \mathrm{mg} . / \mathrm{kg} . /$ day, $50 \mathrm{mg} . / \mathrm{kg}$. day, $70 \mathrm{mg} . / \mathrm{kg}$. $/$ day or $100 \mathrm{mg} . / \mathrm{kg}$./day. Therefore the single doses administered were $6 \mathrm{mg}$. $/ \mathrm{kg}$., $9 \mathrm{mg}$. $/ \mathrm{kg}$., $12 \mathrm{mg}$. $/ \mathrm{kg}$., and $18 \mathrm{mg}$./ kg. Results of the determinations are shown in Table IV.

\section{Results}

All of the patients recovered. The response of eight patients to cloxacillin therapy was considered to be excellent. Eleven children had satisfactory, but not dramatic responses, and six patients had prolonged courses. All six of these children had empyema when treatment was initiated. The slow improvement may have been an expression of the extensive pathology in the patients with empyema, however, difficulty in establishing adequate drainage was felt to be the most important cause of the prolonged morbidity. In one instance a low dose of cloxacillin may have been a contributing factor. An analysis of the cases with extended courses is presented in Table $\mathrm{V}$.

The children all tolerated both the parenteral and oral forms of the drug well. The only evidence of toxicity in this group of 25 patients was a rise of the S.G.O.T. in four patients. In three instances the S.G.O.T. returned to normal promptly when the drug was discontinued. The fourth patient was lost to follow-up.

\section{Summary and Conclusions}

The morbidity and mortality figures for 54 cases of primary staphylococcal pneumonia in children treated at Ben Taub General Hospital, Houston, Texas, were analyzed. The cases occurred from 1954 to 1964. During this period three different antibiotic treatment regimes were employed. From 1954 through 1957 penicillin $\mathrm{G}$, chloramphenicol, erythromycin or novobiocin were used alone or in various combinations. During 1958 and 1959 bacitracin and kanamycin were employed. The drugs used since 1960 have been methicillin, oxacillin, or cloxacillin.

The morbidity has been strikingly decreased during the last two regimes. The mortality appears also to have decreased; however, the number of cases studied is too small to establish this fact. It is noteworthy that the deaths which occurred during the 1958-1959 regime were in patients who had been urtsuccessfully treated with penicillin and hat: far advanced disease when kanamycin treat ment was initiated. It is our impression that there may be no real difference in the mo bidity or mortality in patients treated wit kanamycin or bacitracin and those treated with the parenteral penicillinase-resistant penicillins? The latter group of agents has the very definite advantage, however, of having a lower toxicit potential. The low incidence of serious reactions to the penicillinase-resistant penicit lins simplifies the management of patients ang it encourages the early initiation of ant staphylococcal therapy.

A study designed to assess the efficacy and side effects of the parenteral form of cloxacip lin was conducted from January to June 1964 Twenty-five patients with serious pneumonie processes were included in the study. Tho etiologic types of pneumonia were staphylococcal pneumonia, pneumococcal pneumoniक streptococcal pneumonia and pneumonia of unknown etiology. The doses of cloxaci in this study ranged from $35-200 \mathrm{mg}$./ kg./ dage The parenteral route was employed in 240 of the 25 cases.

Serum concentrations of cloxacillin wre performed on five children following single intramuscular doses. The doses selected were one-sixth of the daily dose since the total dailo amount was administered in six doses. Tho height and duration of the drug levels attainef were directly related to the size of the doses Peak serum levels occurred at one-half hour using four different dose schedules.

All of the cloxacillin treated patients recovered. Eight had excellent responses, 1 楼 responded satisfactorily. Six patients admittewith empyema had prolonged courses. The slow recovery in these six children wa\& thought to be due to extensive pathology whe treatment was initiated and difficulty in the establishment of adequate drainage.

Cloxacillin was well tolerated by all of the patients. The only side effect demonstrated was an elevation of S.G.O.T. in four patients. If three instances the S.G.O.T. promptly returneds to normal when the drug was discontinued. The fourth patient was lost to follow-up.

In our experience cloxacillin, like methicillino has been an effective drug for the treatmen of staphylococcal pneumonia. It has also been ${ }^{+}$ satisfactory in the treatment of pneumococcato 
pneumonia. Although the penicillinaseresistant penicillins are not the drugs of choice in the management of pneumococcal infections, their efficacy in pneumococcal disease needs further evaluation because of the frequent difficulty in distinguishing between staphylococcal and pneumococcal pneumonia in infants and children.

\title{
ANTIBIOTICS IN CYSTIC FIBROSIS
}

\author{
A. P. NoRman \\ Hospital for Sick Children, Great Ormond Street, \\ London, W.C.1.
}

IN cystic fibrosis the main problem is the susceptibility of the children to respiratory infection. The clinical course of the untreated case is one of repeated respiratory infections followed by persistent pulmonary sepsis, and later death. Severe attacks may occur in the first weeks or months of life, or less commonly, years may pass with no, or minimal symptoms referable to the chest. Upper respiratory infection is no more common nor severe than in normal children but the maxillary antra usually contain muco-pus from the early years.

The infecting organism is commonly Staphlococcus aureus, but sometimes, and very often after prolonged or repeated antibiotic therapy, Pseudomonas pyocyanea. Table I shows the bacteriological findings in 85 children with cystic fibrosis. A recent paper showed twice the incidence of coagulase positive staphylococci, three or four times the incidence of Pseudomonas pyocyanea, and an equal incidence of hæmophilus organisms in cystic fibrosis as compared to similar groups of children with acute and with chronic respiratory infection. (Iacocca, Sibinga and Barbero, 1963).

It is likely that the type of infecting organism simply reflects the incidence of pathogenic organisms in the local environment of the child, but unlike the normal child, the child with cystic fibrosis is unable to get completely rid of the infection once it has occurred and hence permanent lung damage is the usual sequel.

A possible reason for this is the production by the child with cystic fibrosis of an exessive amount of sticky mucus in response to infection. It is possible, but it is less likely than was once thought, that there is a chemical abnormality in the mucus itself, causing it to be excessively viscid.
TABLE I

Bacteriology of Respiratory Tract in 85 Children with Cystic Fibrosis in Spring, 1964.

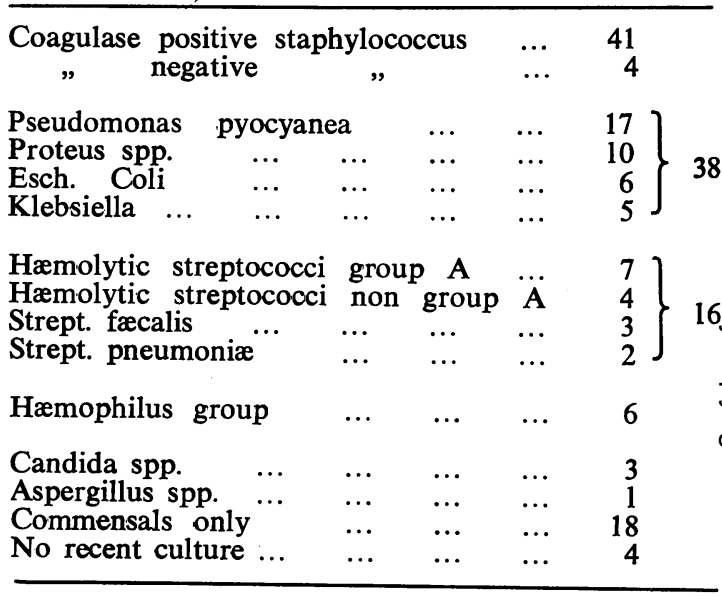

TABLE II

Sensitivities of 41 Coagulase Positive Staphylococci isolated from Children with Cystic Fibrosis

\begin{tabular}{lllllc} 
Penicillin sensitive $+\ldots$ & $\ldots$ & $\ldots$ & $\ldots$ & 12 \\
$\begin{array}{l}\text { Penicillin sensitive } \\
\text { Penicillin resistant }\end{array}$ & $\ldots$ & $\ldots$ & $\ldots$ & $\ldots$ & $6^{*}$ \\
\hline
\end{tabular}

(* all but one of these organisms were methicillin sensitive)

The earlier forms of penicillin were relatively ineffective in the treatment of cystic fibrosis and as can be seen in Table II only 12 of 41 infecting staphylococci were fully sensitive to pencillin G. Antibiotics, such as the tetracyclines and erythromycin gave the first real chance of effective active and preventive treatment of the staphylococcal infection. With the advent of the synthetic penicillins, methicillin has proved extremely effective both clinically and bacteriologically in clearing the staphylococcus from the sputum. Cloxacillin 